\title{
Fruiting Responses and Economics of Containerized and Bare-root Strawberry Transplants Established with Different Irrigation Methods
}

\author{
George Hochmuth ${ }^{1}$, Dan Cantliffe ${ }^{2}$, Craig Chandler ${ }^{3}$, \\ Craig Stanley ${ }^{4}$ Eric Bish ${ }^{5}$ Eric Waldo ${ }^{5}$, Dan Legard ${ }^{6}$, \\ and John Duval ${ }^{7}$
}

\begin{abstract}
AdDitional INDEX WORDs. Fragaria $\times$ ananassa, plant establishment, plug transplants, early yield, economic analysis

SUMMARY. Strawberry (Fragaria $\times$ ananassa) crops were transplanted in two seasons in central Florida with bare-root and containerized (plug) plants under three transplant establishment-period irrigation methods to evaluate crop fruiting responses and production economics associated with the various establishment systems. Irrigation was not required to establish plug transplants in the field. Early (first 2 months) fruit yield with nonirrigated plug plants was greater than early yield with sprinkler-irrigated bare-root plants (the current commercial system) in one of two seasons and equal in a second season. Total-season yields were similar in each season between the two establishment systems. Large or medium plug plants led to greatest early fruit yields in one season while large plug plants resulted in greatest early yield in a second season. Total yield was greatest with medium plants in one season and large plants in another season. The extra cost for the plug plant system was $\$ 1853$ /acre. In one out of two seasons there was increased net income amounting to $\$ 1142$ /acre due to greater early yield associated with the plug plant cultural system. Strawberry plug transplants showed promise for earlier and more profitable crops in addition to substantial savings in water used for plant establishment in the field. The ability to establish strawberry crops without irrigation will be important in areas where growers are required to reduce farm water consumption.
\end{abstract}

C ontainerized (plug) transplants are in widespread use in the vegetable industry for tomato (Lycopersicon esculentum), pepper (Capsicum annuum), watermelon (Citrullus lanatus), eggplant (Solanum melongena), and many other

Florida Agricultural Experiment Station Journal Series No. R-10031

${ }^{1}$ Professor, Horticultural Sciences Department and Center Director, North Florida Research and Education Center, University of Florida.

${ }^{2}$ Professor and Chairman, Horticultural Sciences Department, University of Florida.

${ }^{3}$ Professor, Horticultural Sciences Department, Gulf Coast Research and Education Center, University of Florida.

${ }^{4}$ Professor, Soil and Water Science Department, Gulf Coast Research and Education Center, University of Florida.

${ }^{5}$ Former graduate students, Horticultural Sciences Department, University of Florida.

${ }^{6}$ Former Assistant Professor, Department of Plant Pathology, GulfCoast Research and Education Center, University of Florida. Currently, California Strawberry Commission.

${ }^{7}$ Former Assistant Professor, Horticultural Sciences Department, Gulf Coast Research and Education Center, University of Florida. vegetables and bedding plants. Plug plants typically provide for quicker establishment with less stress to the vegetable plant and with less water required for establishment. New transplant technologies, such as plug transplants, have been developed for strawberry production (Bish et al., 1997, 2001; Durner, 1999; Grout and Millam, 1985; Hochmuth et al., 1998; Poling, 1993a, 1993b, 1993c; Poling and Maas, 2000; Poling and Parker, 1990). Strawberry plug plants are grown from rooted runner tips in cell-trays in a greenhouse for several weeks, and are placed in the field with the root system intact and the growing medium still attached to the root (Bish et al., 2001, 2002). Strawberry plug plant cost is about twice as much as bare-root plants.

Strawberry crops in Florida are currently started from freshly dug bare-root transplants in early fall, under high temperatures. The transplants are grown in northern climates where they experience low temperatures and short day lengths. The plants are placed in the field in Florida under extremely high day and night temperatures in September through October and fruit harvesting can begin as early as late November. Early fruit production is the goal of all Florida strawberry growers because the early fruit (November through January) command higher prices in the market.

Overhead sprinkler irrigation systems are used daily during the 2week plant establishment period to keep transplants fresh and minimize leaf loss (Albregts and Howard, 1984, 1985). The plant establishment phase can account for up to one-third of the total-season water used for the strawberry crop, with as much as 20 inches of water applied during the plant establishment period (Albregts and Howard, 1985). Use of plug plants resulted in significant savings in water applied during plant establishment (Hochmuth et al., 2006). Plugs were established with $290 \mathrm{gal} /$ acre $(50 \mathrm{~mL} /$ plant at transplanting), whereas bare-root plants required 1 million gal/acre from sprinkler-irrigation. Reduced irrigation costs during plant establishment will ultimately save growers money for crop production. In addition, water management districts in Florida may restrict water availability for plant establishment in the near future. Plug

\begin{tabular}{llll}
\hline $\begin{array}{l}\text { Units } \\
\text { To convert U.S. to SI, } \\
\text { multiply by }\end{array}$ & U.S. unit & SI unit & $\begin{array}{l}\text { To convert SI to U.S., } \\
\text { multiply by }\end{array}$ \\
\hline 0.4047 & acre $(\mathrm{s})$ & $\mathrm{ha}$ & 2.4711 \\
29.5735 & $\mathrm{fl} \mathrm{oz}$ & $\mathrm{mL}$ & 0.0338 \\
0.3048 & $\mathrm{ft}$ & $\mathrm{m}$ & 3.2808 \\
9.3540 & gal/acre & $\mathrm{L} \cdot \mathrm{ha}^{-1}$ & 0.1069 \\
0.7457 & horsepower & $\mathrm{kW}$ & 1.3410 \\
2.54 & inch(es) & $\mathrm{cm}$ & 0.3937 \\
25.4 & inch(es) & $\mathrm{mm}$ & 0.0394 \\
0.4536 & $\mathrm{lb}$ & $\mathrm{kg}$ & 2.2046 \\
0.1198 & $\mathrm{lb} / \mathrm{gal}$ & $\mathrm{kg} \cdot \mathrm{L}^{-1}$ & 8.3454 \\
28.3495 & $\mathrm{oz}$ & $\mathrm{g}$ & 0.0353 \\
$\left({ }^{\circ} \mathrm{F}-32\right) \div 1.8$ & ${ }^{\circ} \mathrm{F}$ & ${ }^{\circ} \mathrm{C}$ & $\left(1.8 \times{ }^{\circ} \mathrm{C}\right)+32$ \\
& & &
\end{tabular}


plants had greater leaf area, leaf number, and root growth than bare-root plants during the establishment phase (Hochmuth et al., 2006). Plug plants had begun flowering by 3 weeks into the season, whereas bare-root plants had not. Plug plants can be successfully used to establish strawberry crops with greatly reduced establishmentperiod water requirements; however, higher-value crops from greater early or total yields would help increase the value of plug plants. If faster flowering translates into earlier fruiting with plug plants, then growers would realize increased profits for the strawberry crops. The objective of this research was to evaluate the fruiting responses and economics of plug and bare-root strawberry transplants established with three irrigation practices.

\section{Materials and methods}

This strawberry plant establishment research was conducted in the major strawberry-producing region in central Florida at the University of Florida, Gulf Coast Research and Education Center, in Dover. Strawberry crops were grown with standard strawberry production practices used in the central Florida production area (Albregts and Howard, 1984; Maynard et al., 2000). Details on crop culture for this research study are presented in Hochmuth et al. (2006). Some experimental details will be repeated here for clarity. The experiment was conducted in a split-split-plot arrangement with three factors and four replications in the 1997-98 and 1998-99 seasons. The first factor (main plot) consisted of three plant establishment irrigation treatments (used during the transplant establishment period): sprinkler, microjet, or no irrigation. Details on the sprinkler and microjet irrigation systems are described elsewhere (Hochmuth et al., 2006). All transplants received $50 \mathrm{~mL}$ water with the transplant at planting time. All strawberries were irrigated during the establishment period by drip irrigation for $30 \mathrm{~min}$ every second day to maintain optimal soil moisture under the mulch.

The second factor (sub-plot) was plant propagation method: bare-root or plug transplants. Both types of transplants ('Sweet Charlie') were produced at the same farm in western North Carolina (We-Gro-Rite, Andrews, N.C.). Bare-root plants were field dug mechanically on 2 Oct. of both years and immediately transported to the research site in Florida. Bare-root transplants were kept in a cooler at $40{ }^{\circ} \mathrm{F}$ and the plugs were kept in an open-sided shade house at the field research site until planted. Plug plants were grown in a passively ventilated greenhouse in plastic containerized trays with a cell size of $2 \times 2$ inches square $\times 3$ inches deep, and transported to the Florida research site on 2 Oct. of both years.

The third factor (sub-sub-plot) was the size of the transplant, based on the diameter of the crown of the transplant, measured just above the media surface in the plug trays or at the soil surface line in the case of bare-root plants. In both seasons, three sizes of plants were used, based on crown diameter: small (6-mm-diameter crowns), medium (8-mm-diameter crowns), and large (10-mm-diameter crowns). We chose the crown as the indicator of plant size because the crown is a major energy storage organ in a strawberry transplant and the crown would be an easy, practical plant organ for measuring in a plant-size grading operation on the plant farm.

Strawberry plug and bare-root plants were manually planted in the field in Dover, Fla., on 9 Oct. each year, with two rows of plants on each bed and 12 inches between rows on the bed and between plants in the rows (21,800 plants/acre). Experimental units (plots) consisted of a 20 -ft section of a single bed containing 40 plants.

All plants received $50 \mathrm{~mL}$ of water applied in the transplant hole at planting. No fertilizer solution was applied at transplanting. Immediately after transplanting, the irrigation treatments (sprinkler and microjet) for transplant establishment were begun and continued for 2 weeks. Irrigation treatments were applied from 0900 to 1730 HR each day.

Strawberry plants received $\mathrm{N}$ and $\mathrm{K}$ fertilizers once each week through the drip irrigation system, beginning the third week of the establishment period. The fertilizer was a liquid fertilizer $(4.0 \mathrm{~N}-0.9 \mathrm{P}-4.8 \mathrm{~K})$, formulated from urea-ammonium nitrate, potassium nitrate, potassium chloride, phosphoric acid, calcium nitrate, and magnesium nitrate. The fertilizer solution (specific weight $=10.0 \mathrm{lb} / \mathrm{gal}$ ) was applied at $10.5 \mathrm{gal} / \mathrm{acre}$.

Fruit were harvested manually every second day in the harvest season and graded. Marketable fruit consisted of those fruit greater than $10 \mathrm{~g}$ in weight and free of defects. The harvesting period for the first season was 17 Nov. 1997 to 31 Mar. 1998 and the harvesting season for the second season was 19 Nov. 1998 to 11 Mar. 1999. Strawberry fruit yield was recorded as early (November + December) and total season (November through April) production. Yield was expressed as the number of $10.25-\mathrm{lb}$ flats of fruit per acre.

Data were analyzed separately for each year by analysis of variance for a split-split-plot experiment in randomized complete-block design with four blocks. Main effects and interaction means, when significant, were compared using least significant difference values at $P \leq 0.05$ (SAS Institute, Cary, N.C.). For the analysis, there were three levels of establishment irrigation, the main plots (microjet irrigation, sprinkler, and no irrigation); there were two levels of propagation method, the subplot (bare-root and plug transplants); and there were three levels of transplant size, the sub-sub plot (small, medium, and large). An economic partial budget was developed summarizing the differences in revenue and expenses between production using containerized plugs with no irrigation at planting and production using bare-root transplants with sprinkler irrigation.

\section{Results and discussion}

EARLY FRUIT YIELD. Early fruit command the highest prices and contribute the most to the profitability for strawberry producers in Florida. Very early fruit can be worth as much as $\$ 25$ to $\$ 40$ per flat of strawberries. Fruit responses from the early (November and December) harvest period in the 1997-98 season were affected by the interaction of propagation method and irrigation method (Table 1). Average fruit weight for the early harvest period was similar among all combinations of propagation method and irrigation method, except the combination of bare-root plants with no irrigation. Most bare-root plants in each plot with no plant establishment irrigation died (Hochmuth et al., 2006); therefore there were many instances when no fruit were harvested, leading to a very low mean value for average fruit weight (Table 1). Average fruit weight for nonirrigated plug plants, however, was similar to fruit weight of plants re- 
ceiving sprinkler or microjet irrigation in the establishment period.

Average marketable early fruit yield was negligible for bare-root plants with no irrigation, because of plant loss with no irrigation at establishment. Plug plants with no irrigation resulted in similar early yield to bare-root plants with irrigation, the standard practice used in strawberry production today. In the 1997-98 season large plugs flowered earlier than bare-root plants (Hochmuth et al., 2006), but this earlier flowering resulted in similar early fruit yield to bare-root plants (Table 2).

In the 1998-99 season, average fruit weight was greatest with plug plants, irrespective of the irrigation system used in the establishment period (Table 1). Average fruit weight was intermediate with irrigated bare-root plants, and least with nonirrigated bare-root plants. In the second season, marketable early fruit yield with nonirrigated plug plants was greater than fruit yield with irrigated bare-root plants. In the second season, plug plants of all sizes flowered earlier (Hochmuth et al., 2006) and this earlier flowering resulted in increased marketable early fruit production. It is unclear why plug plants that flowered earlier in each of 2 years (Hochmuth et al., 2006) resulted in earlier fruiting only in the second year. Consistency in early fruit production will be important for plug plant use to be economically viable.

Increased early yields with plug plants, compared with yields with bare-root plants, also were reported for strawberry crops in Egypt (Mohamed, 2000). In a study in North Carolina over two seasons, plug plants led to no early yield advantage over bareroot plants (Butler et al., 2002). The plug and bare-root plants in the North Carolina study came from different geographic production locations in the U.S., while the plug and bareroot plants in the current study were produced at the same location. Also, there might be a greater advantage with plug plants used to establish crops under hotter field conditions in Florida compared to North Carolina.

Early fruiting responses were influenced by the main effect of transplant size (Table 2). In the 1997-98 season, marketable early fruit yield was greater with large or medium plants and least with small plants. Average fruit weight in the second season was greatest with

Table 1. Simple effects for interaction of irrigation and propagation method affecting early and total marketable strawberry fruit yield in two seasons at Dover, Fla.

\begin{tabular}{|c|c|c|c|c|c|}
\hline \multirow{2}{*}{$\begin{array}{l}\text { Transplant } \\
\text { establishment } \\
\text { irrigation } \\
\text { treatment }\end{array}$} & \multirow[b]{2}{*}{$\begin{array}{c}\text { Propagation } \\
\text { method }\end{array}$} & \multicolumn{2}{|c|}{$\begin{array}{c}\text { Early yield } \\
(\text { November }+ \text { December })^{\mathrm{z}}\end{array}$} & \multicolumn{2}{|c|}{ Total-season yield ${ }^{y}$} \\
\hline & & $\begin{array}{c}\text { Avg } \\
\text { fruit } \\
\text { wt }(g)^{x}\end{array}$ & $\begin{array}{c}\text { Yield } \\
\text { (no. flats }^{\text {per acre })^{\mathrm{w}}} \\
\end{array}$ & $\begin{array}{c}\text { Avg } \\
\text { fruit } \\
\text { wt (g) }\end{array}$ & $\begin{array}{c}\text { Yield } \\
\text { (no. flats }^{\text {per acre) })^{\mathrm{w}}} \\
\end{array}$ \\
\hline \multicolumn{6}{|c|}{$1997-98$} \\
\hline \multirow[t]{2}{*}{ None } & Bare-root & 0.8 & 4 & 4.8 & 136 \\
\hline & Plug & 9.7 & 227 & 16.4 & 1683 \\
\hline \multirow[t]{2}{*}{ Microjet } & Bare-root & 10.8 & 212 & 15.1 & 1783 \\
\hline & Plug & 10.5 & 224 & 15.9 & 1647 \\
\hline \multirow[t]{2}{*}{ Sprinkler } & Bare-root & 10.3 & 211 & 14.8 & 1784 \\
\hline & Plug & 10.3 & 201 & 15.9 & 1646 \\
\hline \multirow[t]{2}{*}{ Interaction $\operatorname{LSD}_{0.05}{ }^{\mathrm{v}}$} & & 1.5 & 44 & 1.4 & 192 \\
\hline & & $1998-$ & & & \\
\hline \multirow[t]{2}{*}{ None } & Bare-root & 6.2 & 54 & 9.5 & 438 \\
\hline & Plug & 14.2 & 406 & 15.8 & 1554 \\
\hline \multirow[t]{2}{*}{ Microjet } & Bare-root & 11.0 & 262 & 14.5 & 1449 \\
\hline & Plug & 13.5 & 395 & 15.5 & 1584 \\
\hline \multirow[t]{2}{*}{ Sprinkler } & Bare-root & 10.7 & 246 & 14.3 & 1375 \\
\hline & Plug & 13.2 & 397 & 15.4 & 1565 \\
\hline Interaction $\operatorname{LSD}_{0.05}$ & & 2.1 & 48 & 2.3 & 213 \\
\hline
\end{tabular}

Table 2. Main effects of plant size on marketable early and total strawberry fruit yield in two seasons at Dover, Fla.

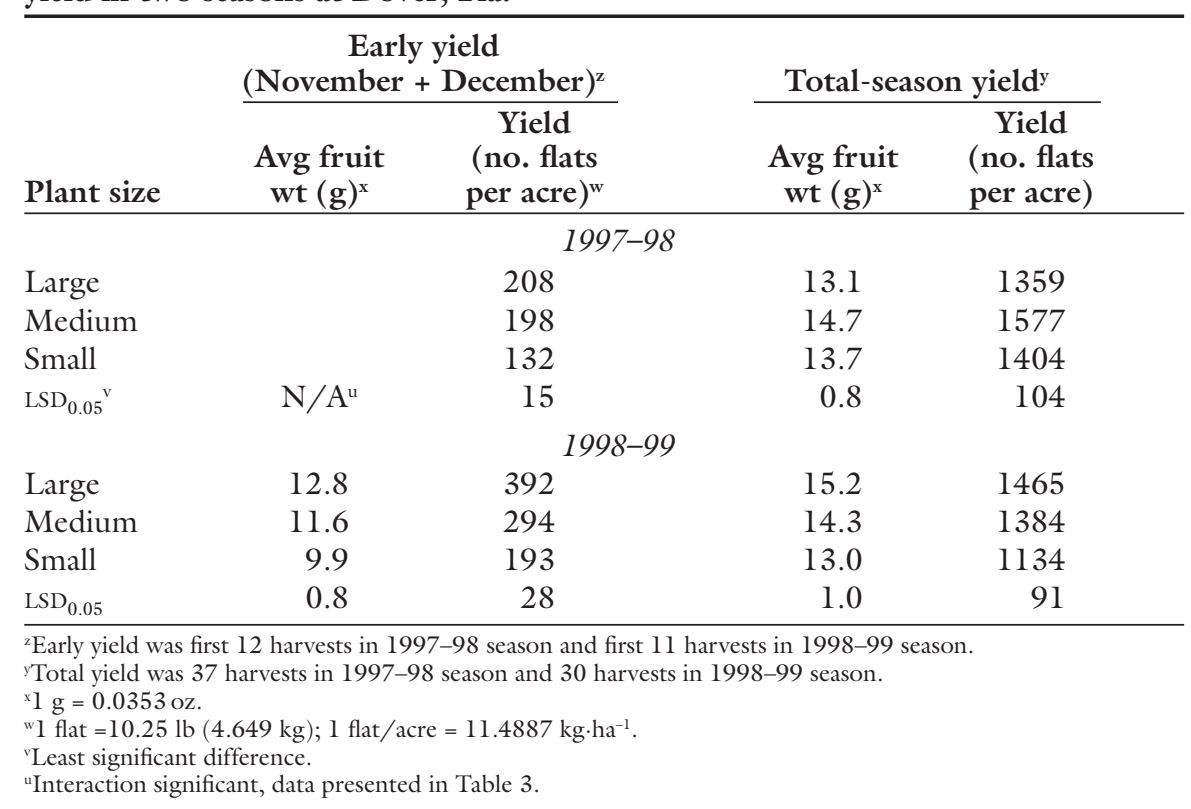

large plants and least with small plants. In the second season, early fruit yield was greatest with large transplants, intermediate with medium plants, and least with small plants. Plug size had variable effects on early fruit yield in a previous study where larger plugs did not always lead to greater earlier yields (Bish et al., 2002). Results of the present study showed that for best early yields, large or medium transplants (minimum 8-mm-diameter crowns) should be used. Large plants in some years will result in greatest early yields but will probably be more expensive than medium plants. At present plugs are not graded and sold by plant size but grading might be required to realize 
the best yield and economic benefits from plug use.

Average fruit weight in the first season was affected by the interaction of irrigation method and plant size (Table 3). Average fruit size was least with any plant size used in combination with no irrigation. With either irrigation system, average fruit weights were similar with large and medium plants and least with small plants.

Researchers elsewhere (Butler et al., 2002; Mohammed, 2000) observed variable early fruiting results with plug plants, an indication that more needs to be learned about transplant production factors governing fruiting responses. Our results showed that plug plants can result in earlier fruit yield which would increase profits on the farm, and that medium or large (8- to 10 - $\mathrm{mm}$ crown diameter) plugs result in earlier yield and greatest early fruit size.

TOTAL-SEASON FRUIT YIELD. Total-season marketable fruit responses in both seasons were affected by the interaction of plant propagation and irrigation method (Table 1). Average fruit weight in the first season (1997-98) was least with nonirrigated bare-root plants. Fruit size was similar with most other combinations of propagation method and irrigation system. Fruit size with nonirrigated plug plants was greater than with sprinkler-irrigated bare-root plants, the current production system used in Florida. Total-season fruit yield was

Table 3. Simple effects for interaction of irrigation method and plant size affecting average marketable fruit weight for early-season yield in the 1997-98 season at Dover, Fla.

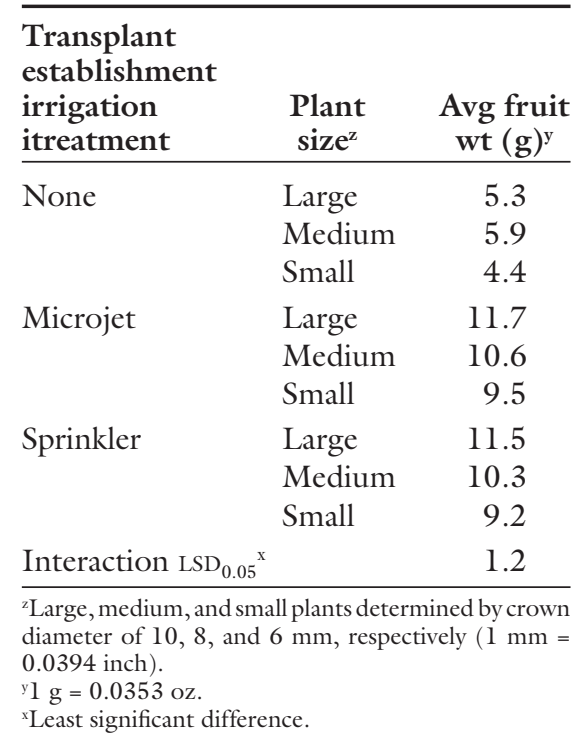

very poor with nonirrigated bare-root plants. Total fruit yield was similar with all other combinations of propagation and irrigation systems. Although totalseason fruit yields were similar with plug plants and irrigated bare-root plants, average fruit weight for the season was greater with plug plants than bare-root plants. Larger fruit are more valuable than smaller fruit, potentially leading to greater season income potential with plug plants.

In the second season, average fruit weights were similar with all combinations of propagation and irrigation systems; all were much greater than with nonirrigated bare-root plants (Table 1). Total-season marketable fruit yields were similar with all combinations of plant propagation and irrigation systems and all these treatment combinations resulted in greater yields than with nonirrigated bare-root plants.

Total-season fruit responses were influenced by the main effects of transplant size (Table 2). In the 1997-98 season, average fruit weight was greater with medium plants, compared with either large or small plants. Total-season fruit yield followed the same trend: greater yield with medium plants. In the second season, large plug plants led to greater fruit size compared with small plants. Response from medium-sized plants was intermediate. Fruit yield was greater with large and medium plants, both of which resulted in greater total-season yield than small transplants.
Fruit yield was not affected by plantlet size used to produce plugs in a study in Alabama (Crawford et al., 2000). In that study, mother-plantlet height (leaf length), was used to define plant size treatments for plugs produced from the mother-plantlets.

In both seasons, total-season yield with nonirrigated plug plants was similar to yield with irrigated bare-root plants, while in one season average total-season fruit size was increased with plugs. Yields with plug transplants were greater than yields with bareroot plants in other studies (Fiola and Lengyen, 1996). In a North Carolina study, total yield in two seasons was similar for two sources of bare-root and one source of plug plants that were produced in different geographic locations in the country; however, fruit size was greater with plug plants in one season compared with one of the bareroot sources (Butler et al., 2002). More work is needed to determine plug plant production practices and field planting systems that lead to more consistency in plug plant fruiting earliness and total fruit production.

Economic estimates. The University of Florida Cooperative Extension Service publishes a summary of production cost estimates for strawberries, using bare-root plants (University of Florida Center for Agribusiness, 2004). This information is summarized and adapted to this project in Table 4, which compares the bare-root

Table 4. Estimated production costs for strawberries using bare-root and plug transplants for Plant City, Fla. (University of Florida Center for Agribusiness, 2004).

\begin{tabular}{|c|c|c|c|}
\hline $\begin{array}{l}\text { Cost } \\
\text { category }\end{array}$ & Cost items & $\begin{array}{c}\text { Costs } \\
(\$ / \text { acre })^{\mathrm{z}}\end{array}$ & $\begin{array}{l}\text { Added costs } \\
\text { due to plug } \\
\text { use }(\$ / \text { acre })\end{array}$ \\
\hline \multirow[t]{5}{*}{ Operating } & Transplants & $2180^{\mathrm{y}, \mathrm{x}}$ & $1853^{z}$ \\
\hline & $\begin{array}{l}\text { Inputs (fertilizer, pesticides, labor } \\
\text { machinery) }\end{array}$ & 2908 & \\
\hline & Irrigation & 668 & -275 \\
\hline & $\begin{array}{l}\text { Miscellaneous (mulch, drip tubing, } \\
\text { predatory mites, transplanting labor, } \\
\text { vehicles, hoe and weed, insurance) }\end{array}$ & 1721 & \\
\hline & Interest on operating capital & 630 & \\
\hline \multicolumn{2}{|c|}{ Total operating } & 8107 & \\
\hline \multicolumn{2}{|l|}{ Fixed } & 3788 & \\
\hline \multicolumn{2}{|c|}{ Total harvesting and marketing } & 14,560 & \\
\hline \multicolumn{2}{|l|}{ Total } & $\overline{26,455}$ & \\
\hline \multicolumn{3}{|c|}{ Additional costs using plugs } & $\overline{1578}$ \\
\hline
\end{tabular}


system cost of production with costs for plug-based production. The use of plug plants increases the amount of input costs for the strawberry producer because plug plants are nearly twice the cost of bare-root plants. Inputs most affected by the use of plug plants are transplant cost and plant establishment irrigation operating cost. Using current 2005 bare-root transplant prices of $\$ 100 / 1000$ plants and plug prices of $\$ 185 / 1000$ plants, the transplant cost increases from $\$ 2180$ to $\$ 4033 /$ acre with plugs, but the costs of pumping water is reduced. Since about onethird of the water used in a strawberry production season is used during plant establishment, it follows that, with plug plants, the pumping costs would be reduced by one-third. This cost (\$275/acre) represents about 3.4\% of the total operating costs for strawberry production. The savings, through the use of plug plants, in pumping costs would impact a small portion of the overall production costs of strawberry. However, if growers are ever required to pay for all or a portion of their irrigation water, then the financial savings in production costs with plug plants could be substantial. Calculations from Table 4 show that overall cost for plug plant use increased by $\$ 1578 /$ acre, consisting of increased cost for plug transplants but savings in machinery costs due to reduced irrigation needs.

There must be a profit advantage in addition to the water savings for plug plants to be economical for current strawberry producers. Increased profit usually results from earlier strawberries. Earlier strawberry production with plug plants occurred in one year of two in our study. Early fruit production (Nov./Dec. 1998) was increased by 160 flats for nonirrigated plug plants over sprinkler-irrigated bare-root plants (Table 1). Early strawberries in Florida typically command prices of $\$ 25$ to $\$ 40$ per flat. The increase in early production with plug plants would pay for the increased cost in plug plants, compared to bare-root plants. For example, the extra cost for plug plants amounts to $\$ 1853 /$ acre and the income for the increase in early yield in 1998 at $\$ 25 /$ flat would be $\$ 4000$ $(\$ 25 \times 160)$. The savings in water used for establishment with plug plants would add more to this profitability. The ability to establish plants with less water would be especially important in potential future situations where growers are required to reduce farm water consumption.

A partial budget specifying the differences in revenue and expenses between containerized plugs and bare-root transplants is presented in Table 5. Costs not directly addressed in the partial budget are assumed to be equal. Additional revenue is derived from the increased early yield based on the 1998-99 yield data in Table 1. Early yields of 406 flats/acre were observed from plug-grown crops with no establishment-period water added, compared to 246 flats/acre for the bare-root system with overhead sprinkler irrigation.

There is a reduction in irrigation variable costs associated with using plugs in lieu of bare-root transplants. Plugs do not require additional water from either overhead sprinklers or a microjet watering system. The reduction in irrigation operating cost is based on the cost avoidance of the repairs and maintenance and energy costs of operating a 10-horsepower pump for an overhead sprinkler system delivering 20 inches of water to plants within $120 \mathrm{~h}$ during the 2 -week establishment period required when using a bare-root transplant system. These savings are $\$ 275$ /acre. Operating costs for the solid-set sprinkler system were taken from Westberry et al. (1998). The operating costs were modified to reflect the $120 \mathrm{~h}$ of operation used in this study instead of the $180 \mathrm{~h}$ assumed by Westberry et al. (1998).

Added expenses of $\$ 1853$ /acre were incurred due to the use of containerized plugs rather than bare-root transplants. There is also a loss of revenue associated with the displacement of 160 flats of fruit from later-season yield to early-season yield. The revenue loss would be the 160 flats displaced times the late-season price, which is assumed to be $\$ 8 /$ flat or $\$ 1280 /$ acre. The expected net return from using containerized plugs is $\$ 1142 /$ acre greater than using bare-root transplants, indicating increased profitability potential under this particular set of assumptions.

Our results show plug plants have potential for increasing profits on strawberry farms. Plug plants did not require sprinkler irrigation for crop establishment, resulting in significant savings in water and the associated irrigation costs. Production practices that result in water savings will be important for strawberry production in urbanizing areas in Florida. More research is needed to determine plug transplant cultural systems that result in consistent early fruit production on the order of the results obtained in the 1998-99 season. Our results with plug transplants should have application for most southeastern U.S. strawberry production regions using the plastic-mulched, raised-bed annual-hill cultural system.

CONCLUSIONS AND PRACTICAL APPLICATIONS. The major findings of this research were:

l. Plug plants can provide earlier fruit yield than bare-root plants without establishment-period irrigation. Marketable early yields were greater with nonirrigated plug plants than with sprinkler-irrigated bare-root plants in one out of two seasons. Fruit size was greater in one of two seasons with nonirrigated plug plants compared with sprinkler-irrigated bare-root plants.

2. Total-season marketable fruit

Table 5. Partial budget of the potential value of using strawberry plug plants instead of bare-root transplants.

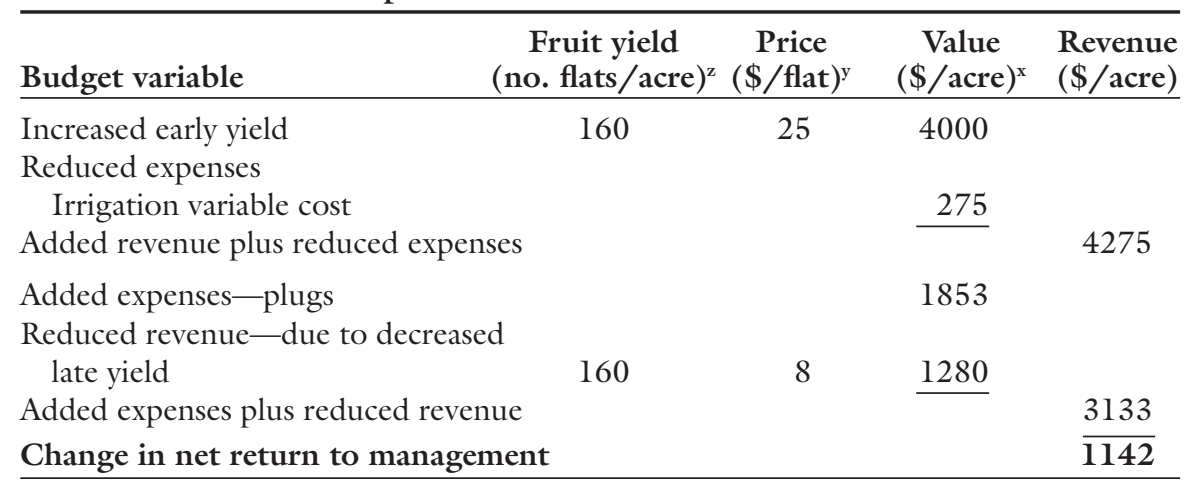

${ }^{2} 1$ flat $=10.25 \mathrm{lb}(4.649 \mathrm{~kg}) ; 1$ flat $/$ acre $=11.4887 \mathrm{~kg} \cdot \mathrm{ha}^{-1}$

'\$1.00/flat $=\$ 0.2151 / \mathrm{kg}$

$\times \$ 1.00 /$ acre $=\$ 2.4711 / \mathrm{ha}$. 
yield was similar with plug or bareroot plants in both seasons. Totalseason fruit size was greater in one season with nonirrigated plug plants compared with sprinkler-irrigated bare-root plants.

3. Plant size was important for early and total yields. Early and totalseason fruit yields were best with large or medium plants. With plugs, the plants should have at least an 8-mmdiameter crown (medium size).

4. The profitability of strawberry production was increased by $\$ 1142$ / acre in one season with plug plants established with water only at transplanting. More research is needed to establish consistency in earliness with plug plants.

\section{Literature cited}

Albregts, E.E. and C.M. Howard. 1984. Strawberry production in Florida. Fla. Agr. Expt. Sta. Bul. 841. Univ. of Florida, Gainesville.

Albregts, E.E. and C.M. Howard. 1985. Effect of intermittent sprinkler irrigation on establishment of strawberry transplants. Soil Crop Sci. Soc. Fla. Proc. 44:197-199.

Bish, E.B., D.J. Cantliffe, and C.K. Chandler. 2001. A system for producing large quantities of greenhouse-grown strawberry plantlets for plug production. HortTechnology 11:636-638.

Bish, E.B., D.J. Cantliffe, and C.K. Chandler. 2002. Temperature conditioning and container size affect early season fruit yield of strawberry plug plants in a winter, annual hill production system. HortScience 37:762-764.

Bish, E.B., D.J. Cantliffe, G.J. Hochmuth, and C.K. Chandler. 1997. Development of containerized strawberry transplants for Florida's winter production system. Acta Hort. 439:461-468.
Butler, L.M., G.E. Fernandez, and F.J. Louws. 2002. Strawberry plant growth parameters and yield among transplants of different types and from different geographic sources, grown in a plasticulture system. HortTechnology 12:100-103.

Crawford, T.D., D.G. Himelrick, J.L. Sibley, and J.A. Pitts. 2000. Effect of runner plantlet size on performance of strawberry plug plants. Small Fruits Rev. 1:15-21.

Durner, E.F. 1999. Winter greenhouse strawberry production using conditioned plug plants. HortScience 34:615-616.

Fiola, J.A. and R. Lengyen. 1996. Plug transplants are superior to dormant transplants for productivity in strawberry plasticulture. Proc. IV North Amer. Strawberry Conf. p. 289-291.

Grout, B.W.W. and S. Millam. 1985. Photosynthetic development of micropropagated strawberry plantlets following transplanting. Ann. Bot. 55:129-131.

Hochmuth, G., D. Cantliffe, C. Chandler, C. Stanley, E. Bish, E. Waldo, D. Legard, and J. Duval. 2006. Containerized strawberry transplants reduce establishment-period water use and enhance early growth and flowering compared with bare-root plants. Hort Technology 16(1):46-54.

Hochmuth, R., L. Leon, T. Crocker, D. Dinkins, and G. Hochmuth. 1998. Comparison of bare-root and plug strawberry plants in soilless culture in northern Florida. Fla. Coop. Ext. Serv. Rpt. SVREC 98-4. Univ. of Florida, Gainesville.

Maynard, D.N., G.J. Hochmuth, C.S. Vavrina, W.M. Stall, T.A. Kucharek, J.F. Price, T.G. Taylor, S.A. Smith, and A.G. Smajstrla. 2000. Strawberry production in Florida, p. 215-220. In: D.N. Maynard and S.M. Olson (eds.). Vegetable production guide for Florida. Fla. Coop. Ext. Serv. Circ. SP-170. Univ. of Florida, Gainesville.
Mohamed, F.H. 2000. Current and future usage of micropropagated strawberry plug transplants in Egypt. Acta Hort. 513:389-392.

Poling, E.B. 1993a. A two-year field comparison of strawberry fresh-dug and plug transplants on plastic mulch. Acta Hort. 348:276.

Poling, E.B. 1993b. Strawberry plasticulture in North Carolina: I. Developing a competitive horticultural industry requires "experts," not "participatory groups." HortTechnology 3:400-402.

Poling, E.B. 1993c. Strawberry plasticulture in North Carolina: II. Preplant, planting, and postplant considerations for growing 'Chandler' strawberry on black plastic mulch. HortTechnology 3:383-393.

Poling, E.B. and J.L. Maas. 2000. Strawberry plug transplant technology. Acta Hort. 513:393-401.

Poling, E.B. and K. Parker. 1990. Plug production of strawberry transplants. Adv. in Strawberry Production 9:37-39.

University of Florida Center for Agribusiness. 2004. Strawberry enterprise budget. Plant City. Fla. Coop. Ext. Serv. 22 Oct. 2005. <http://www.agbusinesscenter. ifas.ufl.edu/cost/cop03-04/Strawberries.doc>.

Westberry, G. and K. Harrison. 1998. Solid set irrigation. Univ. of Georgia Coop. Ext. Serv. 22 Oct. 2005. <http://www.ces. uga.edu/Agriculture/agecon/templates/ SOLIDSET.WB2>. 